\title{
Constructing Meaning: The Albany Exhibition of David Smith's Medals for Dishonor
}

\author{
Paula Wisotzki, Loyola University Chicago
}

All art $($ C Estate of David Smith/Licensed by VAGA, New York, NY

When J. D. Hatch, director of the Albany (New York) Institute of History and Art, wrote to David Smith on 6 May 1942 to express his interest in exhibiting the Medals for Dishonor (1936-1940), he offered no indication that he was concerned one way or another with the political content of the series. ${ }^{1}$ His interest seems to have been stimulated by the opportunity to display recent work by a regional artist of rising reputation. But for Smith, a committed leftist as well as an avant-garde artist, Hatch's invitation struck at the heart of issues that had consumed him for several months: the meanings conveyed by these fifteen lowrelief medallions in the midst of the United States of America's (USA) involvement in World War II, and how the series could function in a political environment different from the one in which it had been produced.

For much of the 1930s Smith had shared with a number of his fellow artists a Marxist framework for interpreting world events. During the same period he had joined left-leaning professional organisations and participated in public demonstrations in support of workers' rights - affiliations and activities which brought him into a community of like-minded colleagues. However, after 1939, Smith's steadfastness in seeking to align himself and his art with the positions of The Communist Party of the United States of America (CPUSA) set him apart from much of the New York art world. ${ }^{2}$

Many American leftists had their faith in the political movement sorely tested by a series of events in the late 1930s. The position of the Union of Soviet Socialist Republics (USSR) as the legitimate leader of the international communist movement had been severely undermined by the continued reports of Stalinist purges, followed by the Nazi-Soviet Non-Aggression pact of August 1939. These matters came to a head for many in the New York art world, as in other sectors of society, with the USSR invasion of Finland of November 1939. When aid to the Finns was contentiously debated by the American Artists' Congress (AAC) in April 1940, the membership fragmented over the leadership's refusal to condemn Soviet aggression. ${ }^{3}$ The AAC soldiered on with Smith as a member, but the cumulative effect of these events was to eviscerate the support which it - and other leftist organisations - had previously enjoyed.

A case study of Smith's 1942 preparations for the exhibition at the Albany Institute of History and Art makes it possible to follow an artist who had not set aside his leftist engagement in the wake of the Soviet invasion of 
Finland, but instead had worked to position himself and his art in a way which complemented CPUSA goals during the war. ${ }^{4}$ Further, this episode in Smith's career is a remarkable instance of an artist seeking to control and, in fact, alter the meaning of his work after it passed out of the studio, and even beyond its initial exhibition. It reveals both the possibilities and the difficulties of such an enterprise, especially for a politically committed artist maneuvering to keep pace with current events. While undertaking these changes, Smith was very specific in stating that his "thesis" had not changed, rather "the world has changed around [him]." 5

In attempting to redirect the meaning of the medals in preparation for the Albany exhibition, Smith gave the series a different name, altered its composition by eliminating four of the fifteen original objects, and provided new titles and captions for the individual works which remained. In making these changes, he transformed the medals from what he termed an antiwar statement (although in actuality the series was both against the war and opposed to Fascism) into an anti-Fascist one - a shift in keeping with his changed attitude toward the war and consistent with the contemporary communist party position. The process of reshaping the content of the medals was both facilitated and frustrated by the complex imagery of the objects and the accompanying written material created for their first exhibition almost two years earlier at the gallery of Smith's dealer,

Marian Willard, in New York City. ${ }^{6}$ The medals' strong social agenda expressed through a Surrealistinfluenced treatment of forms seemed to confuse some critics at the time of the Willard Gallery exhibition, but the series attracted a good deal of publicity, most of it positive — or at least respectful — in tone. ${ }^{7}$ This initial exhibition helped to further the sculptor's

MEDALS FOR DISHONOR

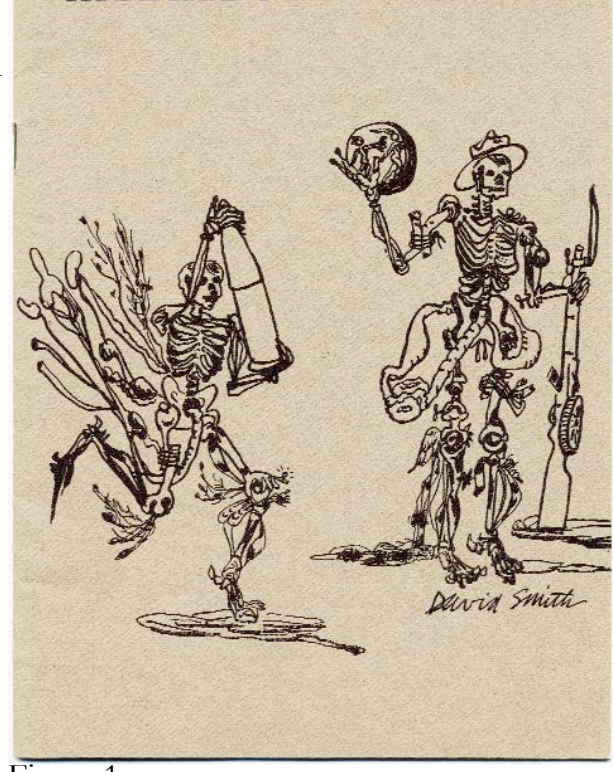

Figure 1 reputation, but despite this "success d'estime" (as Smith would later refer to his early recognition in the press), no outright sales resulted from the exhibition. However, Willard savvily recognized

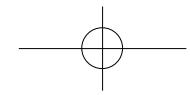


that, in the absence of sales, she had on hand in her gallery a complete set of the medals which formed a ready-made exhibition - one that was coherent, easily transportable and, thanks to arrangements made for the Willard Gallery showing, could be accompanied by a catalogue (Fig. 1).

By February 1941 Willard had arranged for the series to go on view at the Kalamazoo Institute of Art. ${ }^{8}$ No alteration to the series was made; all fifteen works were shown, the original series title was employed, the exhibition passed without incident, and the medals were returned to the Willard Gallery in April 1941. ${ }^{9}$ However, when the works were unpacked, it was discovered that two of the metal plaques had been dislodged from the wooden mounts supporting them. ${ }^{10}$ As a result of this random event, Willard felt that she could no longer circulate all fifteen of the medals. Although, at the time, this development was viewed by dealer and artist as no more than a pragmatic if somewhat annoying issue, therein lay the seeds of rethinking the medals as something other than an integral group of fifteen works.

Nonetheless, the series as a complete unit had meant something very specific to Smith when he produced it. In July 1940, he had written to a colleague describing the works as "a series of antiwar medals." 11 This blunt pronouncement of the nature of the medals was reinforced by their imagery, their original titles (both collective and individual), and sustained by the catalogue that

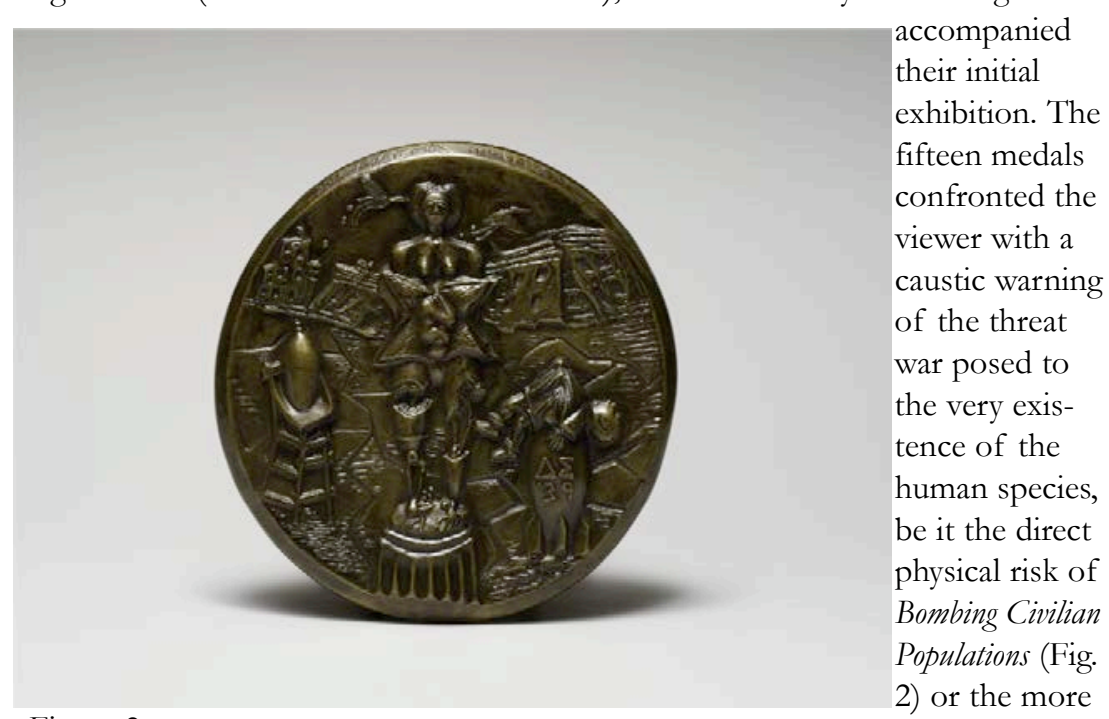

Figure 2

abstract shadow cast by capitalist profit motives in Munition Makers (Fig. 3). At the same time, the series attacked those who were supportive of and benefitted from any war through the ironic device of providing medals for services ren- 
dered. The perspective expressed in the medals reflected Smith's leftist political beliefs. In 1940, for him to generalize that position by employing the term "antiwar" put him in sync with the current position of the CPUSA, which, with the 1939 Nazi-Soviet Non-Aggression Pact, had set aside the anti-Fascism of the Democratic Front era in order to align itself with the USSR. ${ }^{12}$

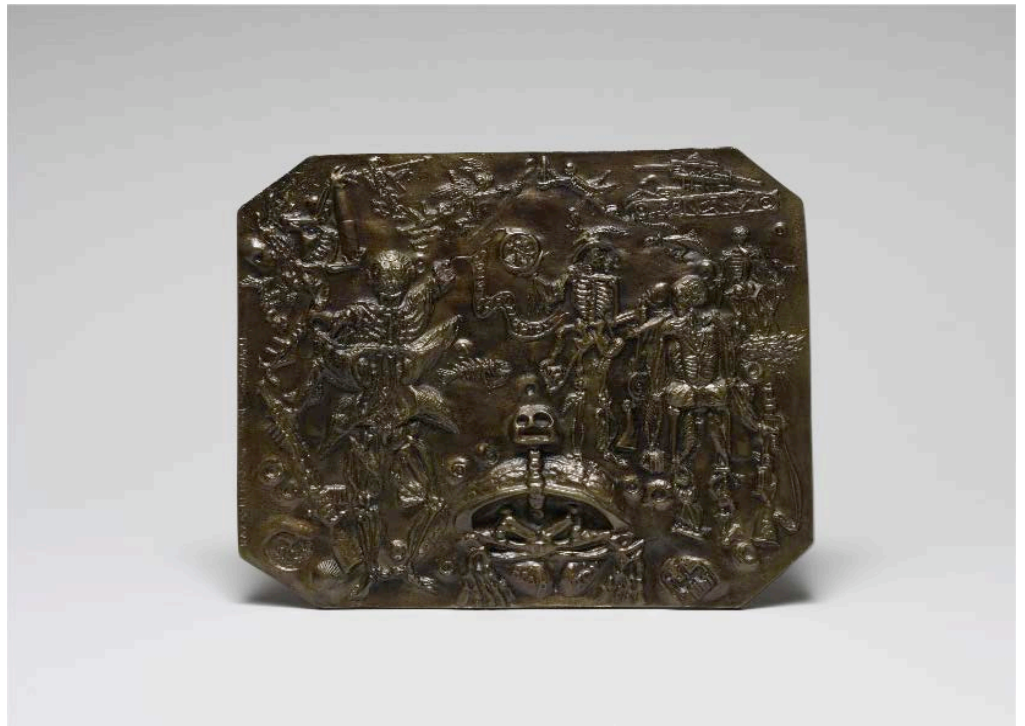

Figure 3

However, a close reading of the political content of the medals as Smith presented them in 1940 reveals a series which was more than antiwar; it was also decidedly anti-Fascist in tone. Further, the medals addressed class tensions in the USA. This sophisticated, multi-layered assessment of the world's problems was shaped by Smith's interpretation of Marxist theory and communist party practice in the late 1930s when the medals were conceived and executed. However, that same complexity sometimes hindered Smith's attempts to redirect their meaning at later points in their history.

Although the medals had originated in the anti-Fascist era of the Democratic Front, it was reasonable for Smith to see an antiwar position as coexisting with an anti-Fascist one; after all, the rallying cry of the American Artists' Congress (founded in 1935) was “Against War and Fascism." These potentially conflicting goals were united by Democratic Front organisations in an attempt to preserve the notion of class warfare at a time when the defeat of Fascism had become the paramount concern of the CPUSA. That the working classes had nothing to gain from a conflict between imperialist forces, and therefore should refuse to participate in organized hostilities amongst nations, was a 
carryover of ideas from the Third Period when capitalist democracy and Fascist authoritarianism were considered two forms of the same enemy (a position encapsulated in Smith's medal War Exempt Sons of the Rich [Fig. 4]). ${ }^{13}$ However, given the immediate threat posed by Fascist governments, their defeat became the primary operating principal of the Democratic Front.

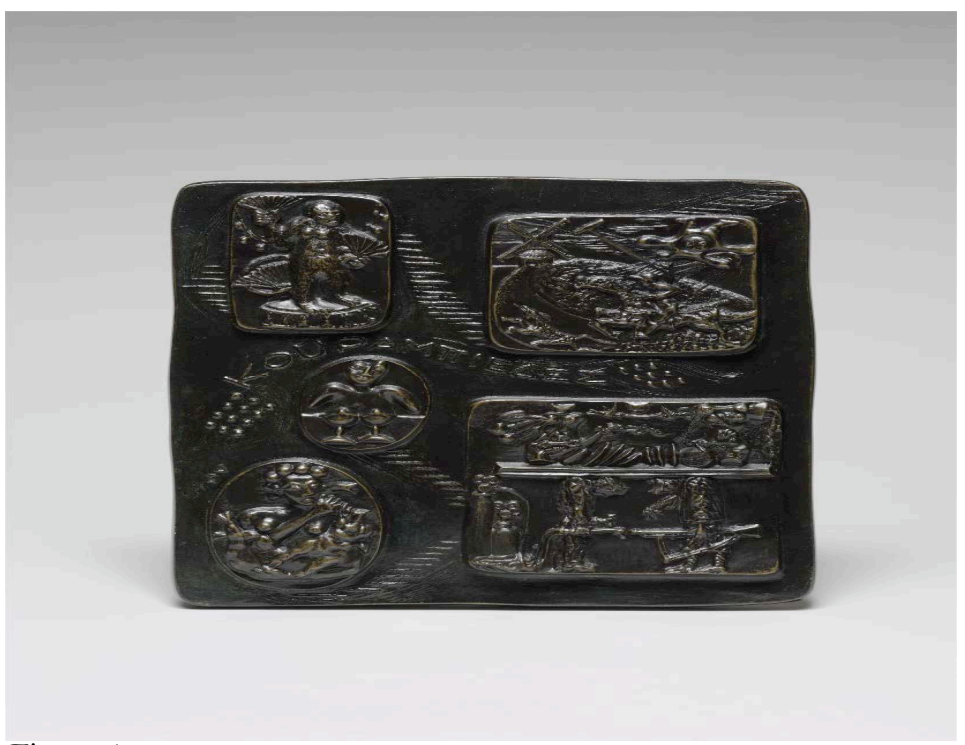

Figure 4

This necessitated a new distinction between Fascism and western democracies, and war became the lesser of two evils.

Thus, Smith's intermingling of antiwar and anti-Fascist messages in the medals responded to the political climate of the late 1930s as he understood it, combining his awareness of the rise of Fascism, the threat of global war, and the economic oppression of the lower classes. Centred around these concerns, the medals serve as a veritable litany of the world's ills. The antiwar message was primarily couched in terms of the suffering inflicted on civilians - for example in Bombing Civilian Populations and Sinking Hospital and Refugee Ships (Fig. 5). The threat posed by Fascism operated as an undercurrent in some of the same objects, for example, despite its generalized title, Bombing Civilian Populations was inspired by the Luftwaffe's infamous bombing of Guernica. But in the world of the medals, Fascism was also a very real presence in the United States through individuals and organisations which manipulated the press, encouraged false nationalism and promoted racism, as demonstrated by Fourth Estate (Fig. 6), and Private Law and Order Leagues (Fig. 7). 


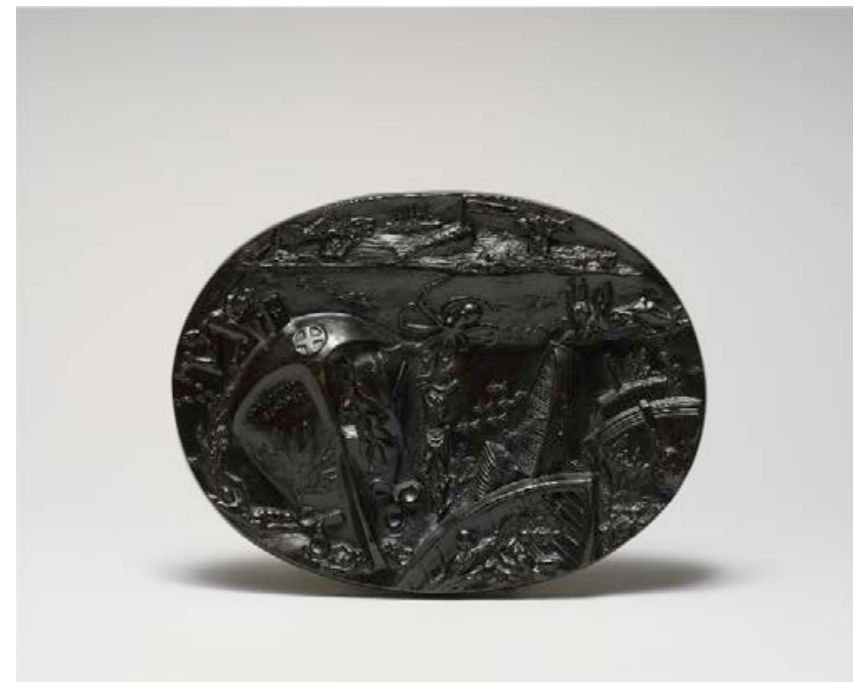

Figure 5

Overall, it was class warfare which remained uppermost in Smith's thinking. A recurring theme was the exploitation of the poor by the rich which took place with the complicity of the clergy and the medical professions, and the assistance of industries ranging from munitions to agriculture (Cooperation of the Clergy [Fig. 8], Reaction in Medicine [Fig. 9], Munition Makers, and Food Trust [Fig. 10]).

It was only after Smith sought to legitimize the medals in response to the USA's entrance into World War II that he came to speak of them as antiFascist. In changing the primary label used to characterize the medals, there was an implied shift in their political meaning. While an attack on Fascism was integral to the medals' conception and execution, by 1942 the issue became the precise nature of the anti-Fascism with which Smith associated the medals. At a time of war, the intermingling of leftist causes set forward with the initial exhibition of the medals no longer comfortably served Smith's political goals. With the Fascist enemy now defined as specifically and exclusively exterior to the Allies, Smith's class-based, global perspective was no longer completely useful. In order for him to offer the unadulterated support for the war called for by the new political reality, he needed to present the medals (and their message) from an exclusively Allied point of view. He was forced to come to terms with antiwar aspects of the medals, their intimations of Fascist elements in the USA and Marxist critique of the world's economic system. The assumption that the medals were antiwar was reaffirmed without equivocation as late as June 1941, when Willard sent seven of the medals to the exhibition accompanying the fourth meeting of the American Artists' Congress (AAC). ${ }^{14}$ Participation in this exhibition reaffirmed the parallel between Smith's concerns and those of other 
politically-active, left-leaning artists (Ernest Crichlow, William Gropper, and Louis Lozowick were among the other exhibitors) in the months immediately preceding the USA's entry into World War II. The medals on view were those

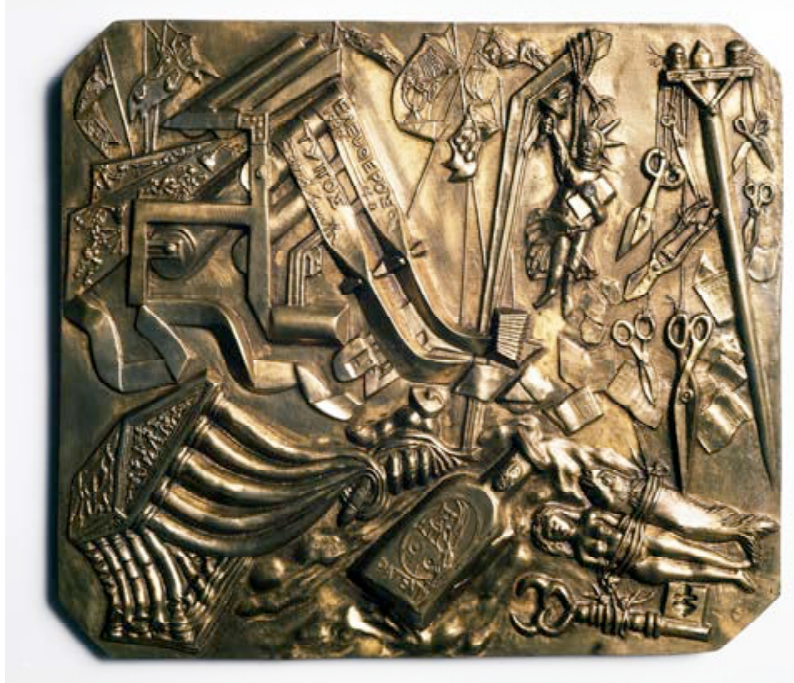

Figure 6

illustrated in the original catalogue (copies of which were for sale at the AAC exhibition), effectively establishing a subset of the series and reinforcing the ties between the objects and the catalogue, a connection which would factor into Smith's later attempts to redefine the medals. ${ }^{15}$

The medals' individual forms were rendered with great detail, but the sheer volume of elements, and the manner in which they were juxtaposed, made it difficult to interpret the works. "Social surrealism," Stanley Meltzoff's term for the medals, usefully captured the manner in which the series functioned as a socially conscious art with links to modernism. ${ }^{16}$ Smith described the medals as "a combination of realism and symbolism which to be best understood must have literary exposition," and used the catalogue to provide that commentary. 17 Nonetheless, the evocative language of that prose (influenced by the writing of James Joyce) paralleled the imagery of the medals without literally describing or explaining it. Smith would later exploit the open nature of the images, the text, and the relationship between the two, as he repositioned the series. However, the radical message of the medals went unchanged and unquestioned into the 1941 exhibition, their brand of social-protest art completely at home in the world of the AAC.

Yet even early in 1941 there were concerns about the subject matter of the medals and how certain audiences might respond. These did not deter 
Willard from aggressively seeking exhibition opportunities for the works, but did affect the way she described the medals to potential exhibitors. When Willard wrote to Elodie Courter, staff member at the Museum of Modern Art, hoping to convince her to include the medals on the museum's list of travelling exhibitions, she hinted that certain venues would probably not be receptive to the medals: "Because you arrange the circulating exhibitions and know the temper of the communities you will know whether or not these would be good for you." 18 And, barely a month later, in an attempt to extend the mid-west travels of the medals, Willard wrote to Katharine Kuh, who worked at the Art Institute of Chicago, inviting her to show them after their exhibition in Kalamazoo, but cautioning her: "This of course would depend on your program and the interest

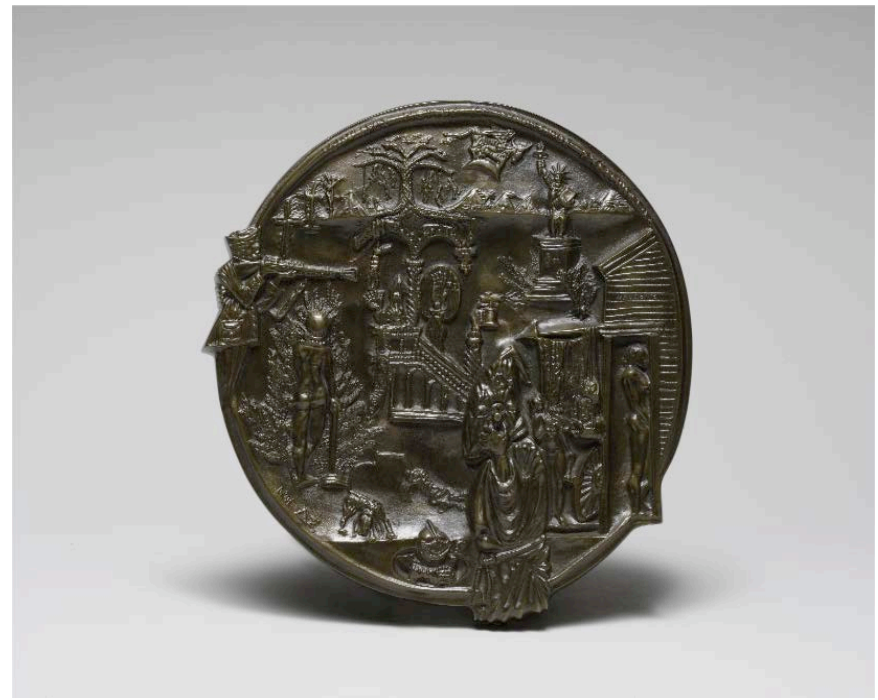

Figure 7

you might have in these very timely, but rather powerfully truthful statements."19

By the end of the year, however, circumstances changed. The USA's precipitous entrance into World War II significantly raised the potential that certain communities would find the medals troubling. This necessitated a rethinking of Willard's strategy of acknowledging potential problems associated with the series' subject matter while continuing to solicit exhibition opportunities.

Although Smith had not taken the lead in seeking out places to show the medals in the year following their initial exhibition at the Willard Gallery, there was every indication that he saw the "package" (the metal plaques, the catalogue, the title, etc.) as continuing to operate as a cohesive unit during this period. ${ }^{20}$ The Japanese bombing of Pearl Harbor galvanized Smith to re-enter the decision- 
making process regarding the medals. His initial reaction was to withdraw the entire body of work from further exhibition, instructing Willard on 16 December 1941, "[w] hen the medals come back lets take them off the showing for the duration." 21 Willard offered no protest, but instead concurred with the artist's position, and with this exchange all seemed settled regarding the medals: while the country was engaged in armed conflict, they were not to be exhibited. 22 This strategy seemed guaranteed to avert any negative reaction to the works' antiwar message.

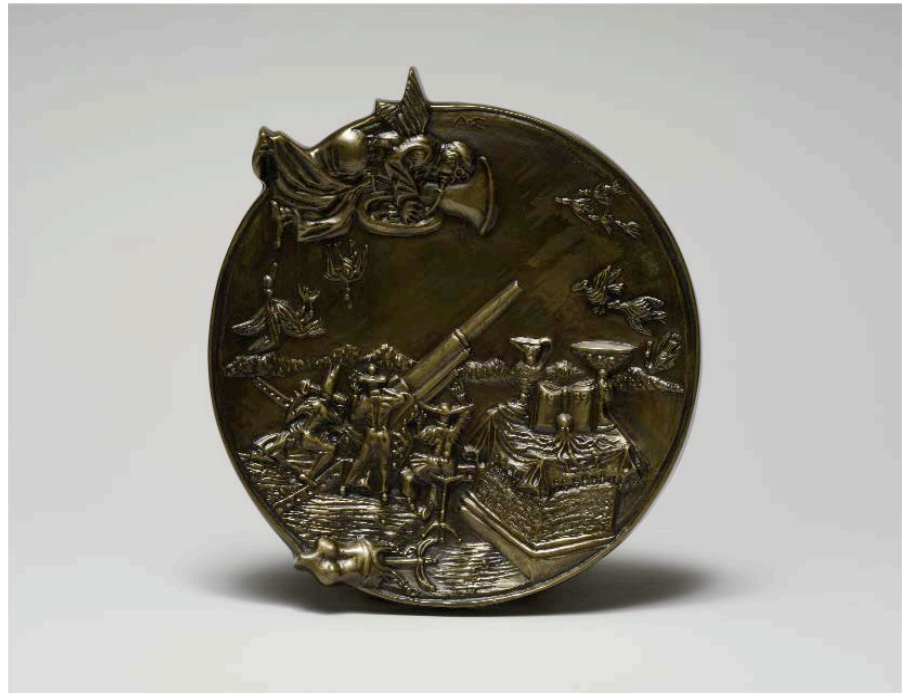

Figure 8

But these conclusions had been reached in the abstract. In reality, the medals were on view at the Walker Art Center in Minneapolis and, even before 7 December 1941, had stirred up precisely the sort of reaction Willard and Smith sought to avoid. However, Smith only learned of these developments after the fact, in a letter from J. LeRoy Davidson, assistant director of the Walker, which enclosed a review of the exhibition published in the Minneapolis Daily Times on 26 November 1941.23 By delaying his missive until mid-January, Davidson effectively removed Smith from any controversy surrounding the exhibition, which had closed at the end of December. Further, Davidson's letter carefully avoided suggesting that Smith was responsible for what had transpired in Minneapolis, and in no way implied that the artist was required to explain or defend his work. Yet confronted with published evidence of the medals' reception in Minneapolis, Smith felt obliged to respond, composing a detailed letter illuminating his views on the medals in the wake of the USA's entrance into the war. This text laid the 
groundwork for a defence of the series which would eventually obviate the decision to withdraw it from exhibition. ${ }^{24}$ As he wrote his letter, Smith drew upon his long-held political beliefs but he also reacted directly to the clipping

Davidson sent him. ${ }^{25}$ The journalist's reading of the medals as not merely antiwar but anti-American zeroed in on one of the more problematic aspects of the series for Smith as he sought to re-position the medals as anti-Fascist and supportive of the Allied war effort.

The review also offered information about Davidson's handling of the local community's hostile response to the series. Davidson was quoted as offering praise for the medals couched in terms of their technical achievement, but this circumscribed acclaim for the work appeared along with an unvarnished disclaimer disassociating the Walker from the medals' subject matter. The fact that Davidson felt compelled to make such a statement suggests just how volatile the subject matter of the medals had become in late 1941. By attempting to focus attention on the technical aspect of the medals, Davidson struggled to separate the works from any timely or precise meaning. Nevertheless, the Willard catalogue had accompanied the medals to the Walker, and given the newspaper's
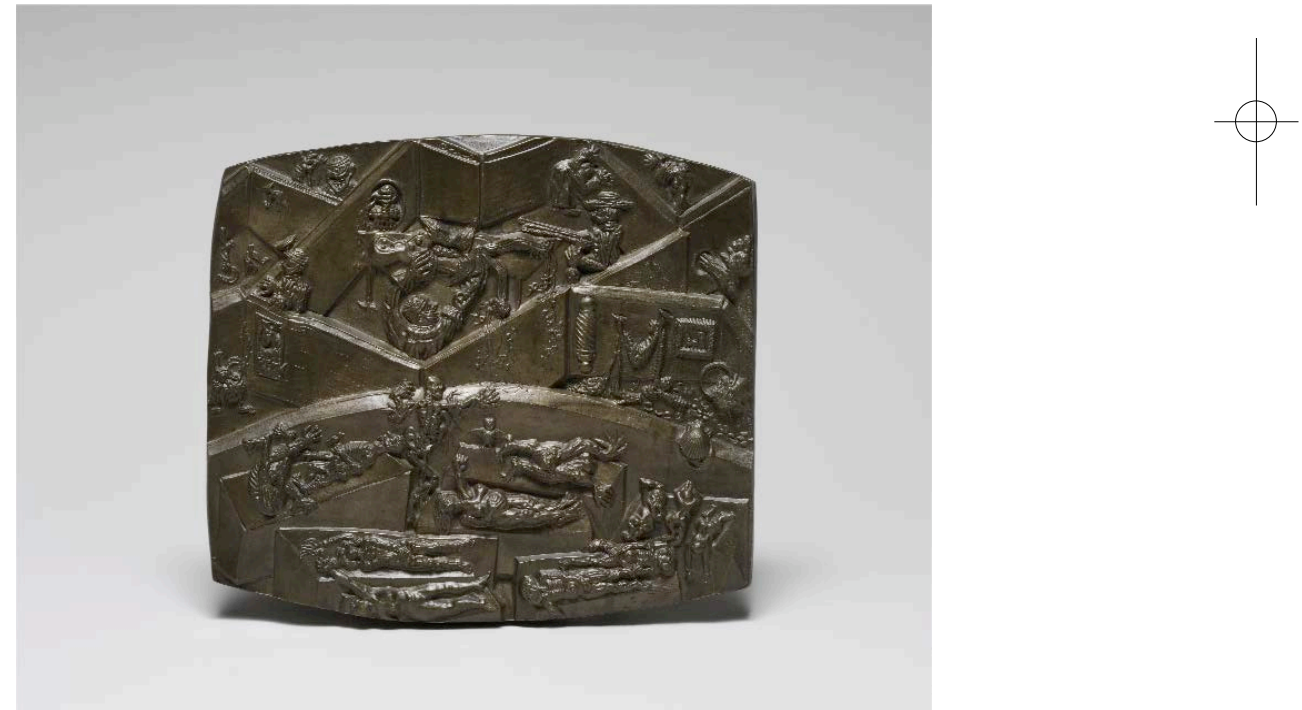

Figure 9

lengthy quotations from it, had been available to the press. The words of the catalogue could only have served to strengthen the impression that the subject matter of the medals was of paramount importance. As Davidson suggested in his letter to Smith, even the titles of the medals could be inflammatory.

It was to the words associated with the medals that Smith first turned 
as he prepared a defence. Recognizing that the written material of the catalogue itself, more than the veiled and complex imagery of the works, had heightened their political message for the reviewer, and potentially for the viewing public, he indicated to Davidson: "Had time permitted I would have had the gallery put in an extra forward insert of clarification." His comment implied that he had contemplated this action prior to the exhibition, but in reality there is no evidence to suggest that he had considered manipulating the catalogue prior to the events in Minneapolis.

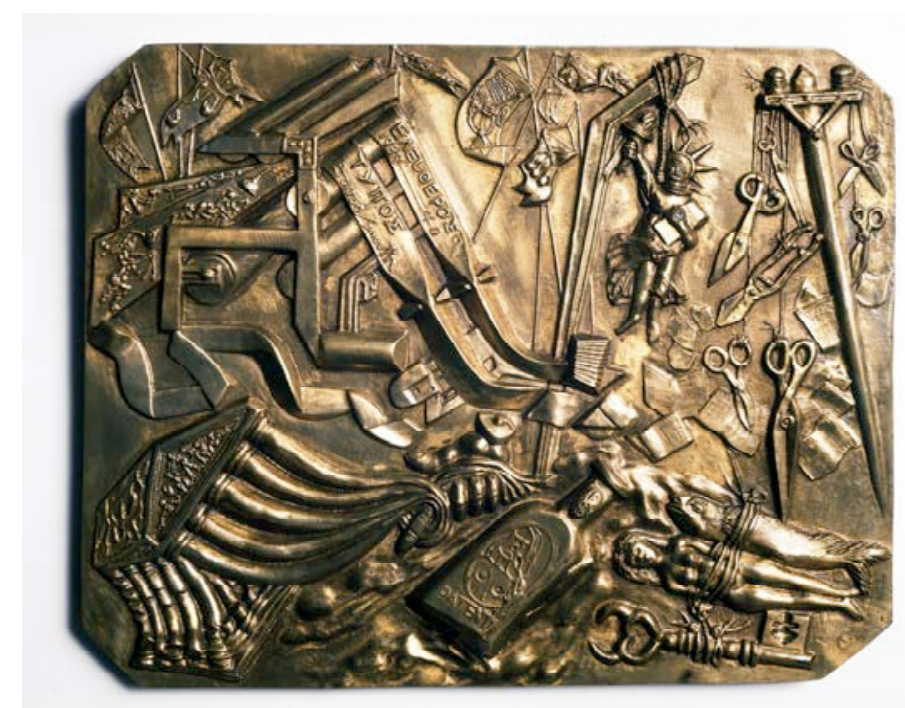

Figure 10

Smith's letter to Davidson offered no specific indication what an addition to the catalogue might have said, but he did provide a lengthy explanation of the medals as he saw them functioning in the current political climate. Without question Smith saw himself as responding to a new set of circumstances which necessitated a different orientation for the series - one which would serve the medals by adjusting their meaning for the wartime context in which they, and the artist, found themselves. As he observed to Davidson, "[s]ince I did those [medals], the world has changed." As Smith sought to reposition of the medals while remaining true to his political convictions, he categorized the entire series as anti-Fascist for the first time, explaining that: "At the time I developed these from 1937 to 1940 they seemed to state clearly to me their anti-fascist - Anti-Fascist element message strong enough that there could be no misrepresentation." Although his shift in focus might seem crude, even abrupt, and in keeping with the most superficial reading of the communist 
party's realignment to protect Soviet interests, in reality Smith's position continued to be more nuanced.

In the late 1930s, along with other leftists, Smith had viewed Fascism's growth as facilitated by the self-interested actions of other nations. It was precisely this perspective that shaped Diplomats (Fig. 11) with its visual references to Neville Chamberlain, Prime Minister of Great Britain, whose capitulations to Hitler's demands to annex the Sudetenland resulted in the Munich Pact of September 1938. In 1942, Smith pointed out to Davidson that "Munich is forgotten, and the British and Halifax are trying to sell out China," suggesting that the appeasement policies practiced by Great Britain in the late 1930s continued to the present day. This was a problematic defence for Smith to offer at this particular historical moment. By demonstrating his sustained anti-Fascism, he provided a powerful example of the consistent political position he claimed for

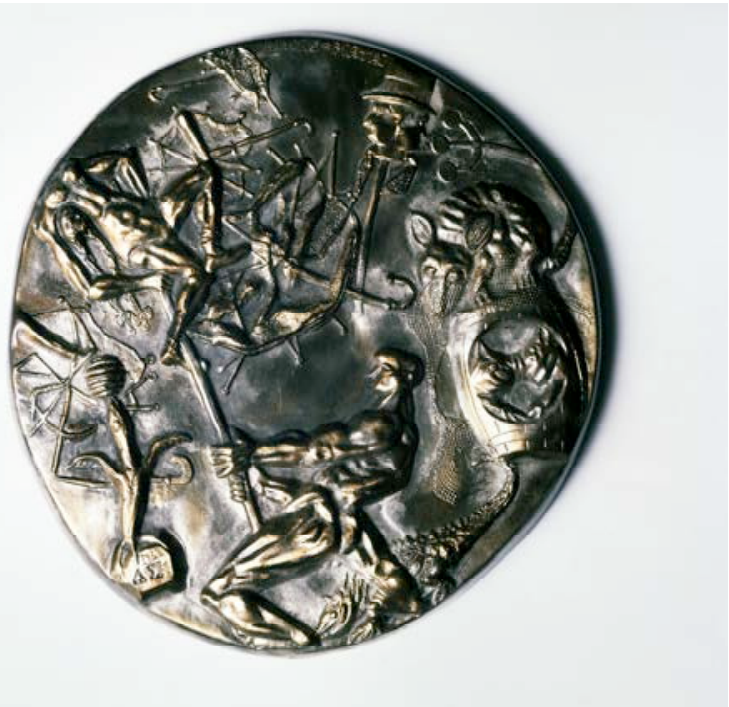

Figure 11

himself. At the same time, his recognition of Great Britain's ongoing imperialist policies hardly reflected uncritical enthusiasm for the Allied cause, as Smith acknowledged: "I don't want anyone to think my ideology herein stated is appeasement or anti-American, it is only aimed at the bad, being prohumanitarian [sic] in the best sense."

For Smith then, even in 1942, pointing out the "bad" was a legitimate component of his anti-Fascism, and extended to his perspective on the USA. If the medals were properly understood, Smith seemed to be saying to Davidson, such observations could not possibly be viewed as anti-American. The ownership of American traditions was highly contested in this period, as it was at other 
moments in the country's history. From 1935 to 1938 the CPUSA employed the slogan "Communism Is Twentieth Century Americanism" as the party positioned itself as the worthy inheritor of American radicalism, while the House Committee on Un-American Activities (established in 1938) attacked the left as outside acceptable national norms. ${ }^{26}$ Negotiating these polar claims of what it

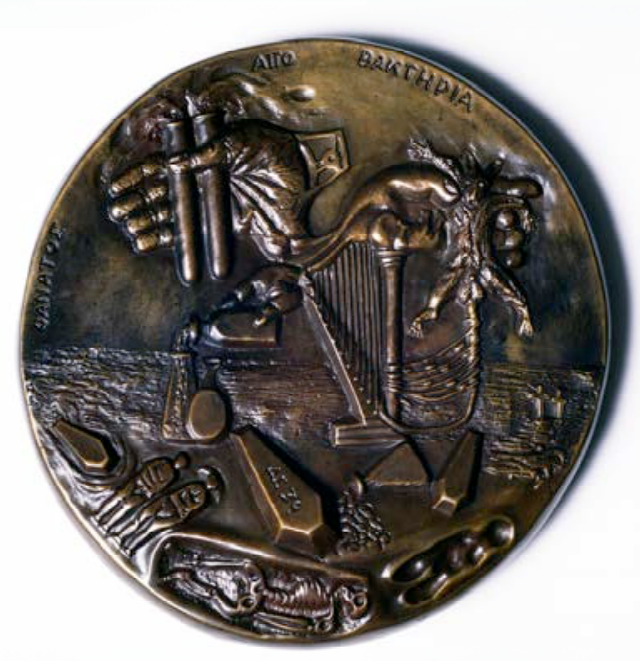

Figure 12

meant to be American was one of the major challenges facing Smith.

When Smith had presented the medals in 1940, his was truly a world view and it was the capitalist system, as much as specific individuals or nations, which he blamed for the evils identified in the medals. From that perspective, the medals were no more exclusively about the situation in the United States than they were about any particular nation. Yet, at the same time, Smith's immediate point of reference, and that of his expected audience, was the USA. Even the original name for the series, with its satirical reference to the highest military decoration bestowed by the United States Congress, seemed calculated to capture the attention of his fellow countrymen. Along with allusions to contemporary events in Europe and symbolism taken from the ancient and medieval worlds, in several instances the medals' imagery and words from the Willard catalogue made specific references to people, groups, and ideas operating in the United States. The Statue of Liberty appeared in both Fourth Estate and Private Law and Order Leagues, thus locating the manipulation of the press and the activities of right-wing organisations squarely in the USA. This connection was further strengthened by the presence of a stylized American flag in Private Law and Order 
Leagues. Another reference to a specifically American institution is the letters "ama" — for the American Medical Association — incorporated into the thick walls of the compound in Reaction in Medicine which shelters physicians from those unable to pay for medical care. The published captions for the medals offered further links to the United States. Among these was a satirical enumeration of the country's fascist organisations — "Black Legion — Klan — Bund — fordstream of Americanism" - from the caption for Private Law and Order Leagues, and in the text accompanying Cooperation of the Clergy, a reference to Depression-era media phenom Father Charles E. Coughlin whose millions of radio listeners heard him openly espouse Fascism by $1938 .^{27}$

Just as Smith did not find it necessary to remake his anti-Fascism in an uncritical mode, neither did he feel it appropriate to ignore the antiwar posture he had earlier associated with the medals. In commenting to Davidson on this topic, Smith acknowledged the war context in which medals now found themselves, and his firm support for the Allied fight against the Axis powers.

However, when it came to the topic of war, once again he was willing to rely on his ability to distinguish between good and bad, refusing to oversimplify as he analysed events, and pointing out the medals attacked "bad elements and institutions which exist and have existed in other wars even wars of freedom." Smith shored up his position with an appeal to authority: "Much of my data comes from government reports and history such as Beard's," implying, as he had done

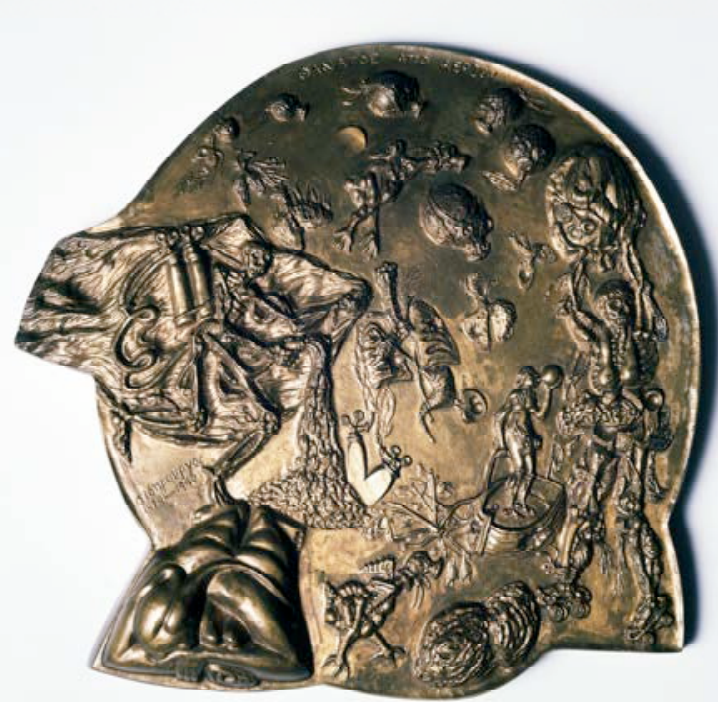

Figure 13 
in explaining his anti-Fascism, that his ideas were founded in reasonable sources and thus part of mainstream thinking, rather than fringe ramblings. 28

After laying out an initial version of his war-time defence of the medals in his response to Davidson, Smith followed up with a letter to Willard where he reiterated that he would add material to the catalogue should there be subsequent exhibitions of the medals: "I'm afraid everybody will misinterpret my point with the medallions - if shown again I'll insert an addenda [sic] specifically pointing to the fact that these are anti-fascist war medals — and pro humanitarian." 29 The eliding of anti-Fascism and antiwar into "anti-fascist war medals," offered an indication of precisely how far Smith appeared to move from the original message of the medals which he had characterized as antiwar. But, as he had with Davidson, Smith went on to stress the discriminating nature of his stance against war, explaining that, "[w] hat I point out are the ills of war — the contradictions of a society — the forces that profit from death - I have never meant that I was against all war — a war for freedom — for revolution is another matter." To Willard, he was comfortable bolstering the legitimacy (and longevity) of his anti-Fascism through references that were more overtly tied to his leftist perspective than those he had used for Davidson: "I am for materials to the socialist state U.S.S.R because it really fights fascism - as I was for the Loyalists in Spain. You know how I feel Marian." Smith reaffirmed that his own ideas had remained steadfast and consistent, even though recent events had altered the attitudes of those around him and necessitating certain adjustments when presenting the medals: "I haven't changed my thesis, the world has changed around me since 1938-39 when I worked the majority of them [the medals]."

In his January 1942 letters to Davidson and Willard, Smith's strategy of employing the catalogue to control public response to the medals was fully established in theory, if not in practice. At the same time he offered ample evidence that he continued to consider the series as a single, coherent unit. In the midst of providing Davidson with a point-by-point refutation of the press's attack on the medals, Smith attributed the fact that all fifteen objects had failed to be sent to the Walker to an unfortunate oversight on the part of his dealer. But, in fact, the ultimate result of Smith having opened the door to repositioning the medals was that all aspects of the series came under scrutiny, including its integral nature. Certainly, given the manner in which he had reoriented the medals by emphasising their anti-Fascist character as opposed to their antiwar message, his initial reaction to the bombing of Pearl Harbor - the decision to withdraw the series from circulation for the duration of the war - no longer seemed necessary. And, although the solution of altering the catalogue was put forward to Davidson and Willard as sufficient to protect and redirect the medals, over the next several months Smith would develop additional approaches to re- 
presenting them.

Smith's first opportunity to take the concept of a wartime remaking of the medals from the theoretical realm and into the real world came with his decision to submit three of the medals to the 1942 Annual Artists of the Upper Hudson exhibition sponsored by the Albany Institute of History and Art - the moment at which Hatch, the Institute's director, most likely became aware of the series. ${ }^{30}$ The medals Smith chose for this occasion were those which addressed atrocities: Death by Bacteria (Fig. 12), Death by Gas (Fig. 13) and Sinking Hospital and Refugee Ships. New titles incorporating the phrase "Axis Devastation" clarified precisely who should be held responsible for these acts - making an unequivocal reference to the conventional, exterior enemy of the Allies. 31

With his preparations for the Annual, Smith ceased to view the medals as a unified block, and two groups began to emerge: those still suitable for presentation and those deemed inappropriate for exhibition in the current political climate. In a letter to Willard around this time, he singled out Munition Makers as an example of a medal that was "still true" but could not "be understood at this time."32 There is every indication that Smith had once considered Munition Makers, with its gleeful skeletal figures waving weapons and money, to be at the heart of the series. 33 However, by the spring of 1942, Smith was unwilling to expose that theme to public scrutiny, viewing the munitions industry as crucial to a now justifiable conflict. The production of war materiel provided essential support to the USA's war efforts as well as those of its allies (notably the USSR). The CPUSA felt obliged to support the Roosevelt administration in its rapprochement with corporate American in order to secure the reorientation of the economy to war production — notoriously working for a no-strike pledge by workers and backpedaling on civil rights issues. 34

Smith seemed confident that his recent decisions regarding the medals — careful selection and new titles — were sufficient to make them presentable at the Albany annual, and to convey his support for the war effort. But in Albany, as had been the case in Minneapolis, circumstances conspired to suggest otherwise. Smith's 21 April 1942 letter to Willard made it abundantly clear that he believed all three medals submitted to the Annual had been accepted. Yet when the exhibition opened in the final days of the month, only two of the works were on view - Death by Gas had been eliminated. 35 No surviving evidence documents the Institute's decision to omit the third medal. But for the Smith "camp," the only possible conclusion was that it had been censored, the action thus serving as just one more reminder of the difficulties associated with exhibiting the medals in the midst of the current world crisis. ${ }^{36}$

This perceived censorship could only reinforce the artist's sense that any presentation of the medals needed to be carefully considered. Still, there was 
every indication that for the Institute, the series continued to be of interest for it was at this juncture that Hatch wrote to Smith expressing a desire to exhibit the Medals for Dishonor (although he referred to the series by the name employed in the Annual checklist — "Axis Devastation"). ${ }^{37}$ The date of his letter, 6 May 1942 , indicated that whatever significance the artist's circle may have attached to the removal of Death by Gas, just one week after the opening of the exhibition Hatch was willing to invite Smith to show the complete series.

Smith worked quickly to send an affirmative, if lengthy, response to Hatch. ${ }^{38}$ Not satisfied with simply accepting the offer to exhibit the medals, he insisted that only eleven of the series could be shown and proposed a number of adjustments to the words accompanying those objects, telling Hatch straight-out the original catalogue was unusable because the "element of time had entered in, which permits only 11 [medals] to be used with the Axis-Devistation [sic] titling." Not surprisingly, among the four to be eliminated was Munition Makers - a medal Smith had identified to Willard as inappropriate for exhibition. Along with it, he separated out War Exempt Sons of the Rich (with its powerful anti-capitalist and antiwar message which would not do in a context that was perceived to require inter-class solidarity to defeat the common enemy), and Cooperation of the Clergy and Reaction in Medicine (each of which attacked the so-called helping professions, and, as was discussed above, made specific references to individuals and organisations in the USA). Interestingly, he did not identify Death by Gas for removal, even though it was the medal presumed to have been censored from the annual exhibition just days earlier. Eliminating medals which might be construed as antiwar or anti-American or both brought the series in line with his current anti-Fascist position. Further, the selection seemed calculated to reduce the series' potential to inflame, and to avoid the sort of negative reaction which had occurred in Minneapolis.

Along with removing four works from the series, Smith provided Hatch with several pages of text for new captions, explaining: "The medallions, I believe would have to be accompanied with a text - printed — mimeographed - or placed near the pieces, since they are somewhat involved and that misconceptions should not arise the viewer could be given a steer key."39 This new material was a heavily — and perhaps hastily — edited version of the captions from the original catalogue. In it, Smith set aside the more complex definition of anti-Fascism he had defended to Davidson and Willard earlier in the year. In many instances his alterations to the written descriptions were as direct as the new titles in their emphasis on the "enemy," and much of the spirit of the flowing, multi-layered, Joycean prose of the originals disappeared in the new attempt to present the medals as directed against the Axis powers.

This resulted in a growing gulf between the words Smith used to explain the medals and their visual reality. Despite having removed four medals 
from the series, the eleven remaining still contained elements which could be construed as anti-American or antiwar or both. For example, to see the medals solely as an attack on the Axis powers was especially forced when two objects incorporated an image of the Statue of Liberty in their iconography. Although the visual elements remained constant, in rewriting captions for these objects, Smith minimized his original references to a situation which threatened the USA from within, instead merely hinting at those who might collude with an exterior enemy. Thus, as he provided a new text to accompany Private Law and Order Leagues, Smith eliminated the names of specific organisations operating in the United States - the Black Legion, the Bund and the Ku Klux Klan — in favor of more general references to "aryan falacies [sic]."

The other new captions which Smith composed for Hatch similarly identified the imagery of the medals as anti-Fascist and included specific references to the war, particularly calling attention to evils associated with Axis powers. Smith's treatment of the caption of Bombing Civilian Populations demonstrated just how straightforward these transformations could be. In this instance, Smith merely cut out the printed caption from the original catalogue and pasted it onto the draft of his letter to Hatch, adding a single sentence: "This is an old Axis cultural practice as employed by the Japs in China the Italians in Ethiopia and Germans in democratic Spain etc." 40 As this action made clear, increasingly Smith's anti-Fascist stance was communicated by words which focused on an enemy "other," and on people, events and places which were of the present references which were directly and immediately supportive of the Allied war effort.

The issue of the medals' timeliness was a significant aspect of Smith's campaign to re-present the medals in light of the United States' entrance into the war. In shifting the medals' focus to the present, he reinforced their connection to the immediate war effort. That the works were "of the moment" was a pivotal point for redefining them away from their antiwar, anti-capitalist origins, and toward their current anti-Fascist orientation. For Hatch, when referring to the series' connection to the present, Smith opposed that concept to the medals' timeless value and in doing so he diverted attention from the manner in which they addressed universal truths, applicable at any time and at any place. For example, as he explained why only eleven of the medals could be part of the proposed exhibition, Smith said of the remaining four: "The others tho true and not deviating from my original thesis - hold a more classic statement than contemporary." 41

In writing to Hatch, Smith used Munition Makers as an example of the "classic statement" of the medals no longer appropriate for exhibition. As it had been in April, this work was singled out to demonstrate why it (and, implicitly, certain other medals) should not be shown at the present time: "while the 
profits, conniving of patents etc, is still true, I don't think it wise to say so as it might confuse people in their war effort." What made Munition Makers "classic" for Smith was the accumulated weight of tradition, rather than exclusive references to the ancient world or to classicism as a visual style. The imagery of Munition Makers provided a panoramic view of history by combining a modern tank, shells, and automatic weapons with a traditional sword, ancient coins, and a prehistoric spear (plus a soldier-figure the artist identified as mediaeval). With these connections to a range of historical periods, Smith indicated that the profiteering of the armaments industry, and the violence and exploitation it engendered, had existed throughout the ages. For Smith, it was "still true" in May 1942 that these were entrenched problems for which no simple solution could be offered, although the defeat of Fascism now took precedence over the evils of the capitalist system.

Despite Smith's speedy response to Hatch's invitation to exhibit the medals in Albany, it was some time before the artist heard anything further about the proposed showing. 42 Once again the worst fears were raised in the Smith household. Dorothy Dehner, Smith's spouse, could only interpret this delay as resulting from Hatch's negative reaction to the medals' political message:

[T] he Albany Museum ... asked David to show his medals (they heard about them but just a little bit) [not enough to get the idea]. So David wrote him practically a book about the medals and what they meant and the guy probably got scared enuf to shit his pants and so we haven't heard a word. So may be its all off I don't know. 43

Nonetheless, her concerns that the abundance of Smith's commentary might have kept Hatch from proceeding with the exhibition were unfounded. Correspondence from later in the summer revealed that there had been further discussions with Hatch regarding an exhibition of Smith's work for the 19421943 exhibition season, and eventually the show was fixed for February 1943. ${ }^{44}$ During this period Smith was contemplating other levels of involvement in the war effort. He was not eager to serve in the armed forces, and in September 1940 when President Roosevelt signed the Selective Training and Service Act which instituted a peacetime conscription for males ages twenty-one to thirty-six, Smith (then thirty-four) wrote to Willard, "I must keep out of an army camp it would spoil my work and ruin me as well." 45 At the time, although Smith expressed his concerns in personal terms, his desire to avoid the draft was consistent with his political position against the war. However, even as he later openly supported the Allies' fight against Fascism, he actively sought alternatives to military service, choosing means which would still demonstrate his support for the cause.

One possibility was for Smith to apply his skills as an artist — specifi- 
cally the challenging process of intaglio carving he had conquered while making the medals - to the war effort. With this goal in mind, he joined Artists for Victory in March 1942, registering as a medalist. When he reported on this development to Willard he indicated that he "[c]ould do some swell Red Cross - Industrial or anti-axis medals." 46 The suggestion that he could make "antiaxis medals" was a direct extension of the anti-Fascist re-presentation of the Medals for Dishonor he had begun to shape in the early weeks of 1942, but the reference to "Red Cross" or "Industrial" medals implied objects which honoured the accomplishments of these entities - a far cry from the critical, sometimes satirical, message offered by the medals already produced.

Nothing came of Smith's proposal to Artists for Victory, but in late May he offered his artistic services to the War Department. Writing to Robert Nathan, chairman of the Planning Committee at the War Production Board, he suggested that he could make "medallions to be awarded for extremely meritorious war production service in industry"; 47 another instance of supporting the war effort by celebrating the "munition makers." His letter to Nathan continued with a fascinating paragraph defending the medals against the negative press they had received in Minneapolis:

A point I want to make regarding the reviews, namely that the medallions were anti-fascist. From 1937 to Pearl Harbor, very few people especially the press, recognized the anti-fascist point of view as being parallel with democratic. Most of the press over-looked this fact. This series hit the dishonorable and destructive elements of society. Certain elements though true might be interpreted as conflicting with the war effort. One fact I wish to re-state - that my basic conception has always been anti-fascist and pro-democratic. ${ }^{48}$

This startling passage appeared without any direct connection to surrounding material (at least in the draft of the letter preserved in Smith's papers). Instead, it loomed like an uncanny memory, revealing just how sharply Smith had felt the criticism, and how keenly he found it necessary to explain his position as a legitimate anti-Fascist.

This emphatic statement of his anti-Fascist position reiterated points made to Davidson, Willard and Hatch earlier in the year. However, the manner in which Smith explained his position to Nathan was somewhat different, acknowledging that he had been anti-Fascist before it was a mainstream position. In doing so, he revealed the leftist politics which made him only "parallel with democratic." These ideas may have appeared out of context in the letter to Nathan, but they served as a reminder that his leftism remained foremost in his thinking. He re-affirmed his belief that the medals' message served the war effort without betraying his political beliefs. If he felt compelled to defend his 
position, he remained eager to claim its legitimacy.

Nothing further developed out of the proposal for War Department employment, but during the same months Smith had approached Artists for Victory and the War Production Board about making medals to support the war effort he had also been pursuing another route to avoid military service. ${ }^{49}$ Beginning in April 1942, Smith began taking welding classes offered through the local Free Defense School. ${ }^{50}$ By refining and expanding his welding skills, he hoped to qualify for a position as a commercial welder, and thus gain the desired draft deferment as an employee of a war contractor. He began searching for a related position, and by July could report to Willard that he was "welding armor plate on tank destroyers 7 days a week" at the American Locomotive Works (Alco) in Schenectady, New York. 51

The job at Alco proved a mixed blessing: On the positive side, Smith was contributing to the war effort, he was able to avoid service in the armed forces, the pay was good, and he found satisfaction in the opportunity to prove himself alongside industrial welders. ${ }^{52}$ However, the long hours of hard labour at the plant severely curtailed his art production, particularly when Smith was forced to take up temporary quarters in rented rooms in Schenectady, several hours' drive from his home and studio at Bolton Landing. But even as his time and energies were absorbed by his industrial labour, and his creative efforts all but suspended, Smith remained actively interested in exhibiting.

While following through on preparations for the Albany exhibition, in October Smith encouraged Willard to submit three of his works - an image of bathers, and two of the medals (precisely which was not specified) to an exhibition being organized by Artists for Victory at the Metropolitan Museum of Art. ${ }^{53}$ When Willard confirmed that she had indeed submitted those works, along with Ad Mare, Smith's response was: "Hope Met shows us — medals and all," suggesting continuing fears that the medals might prove problematic. 54 This concern must have still plagued the dealer as well, for when Willard reported to Smith the jury's interest in two of the works, she commented that they were Ad Mare and "ALSO A MEDALLION 'Private Law and Order Leagues' if you can beat it! No telling how those guys work." 55

Remarkably, after all the concern Smith had previously expressed about the words associated with the medals, the example chosen for the Artists for Victory Exhibition, Private Law and Order Leagues, appeared under its original title in the check list. ${ }^{56}$ Despite the astonishment Willard registered over the medal's acceptance, there was no discussion of the title or caption in Smith's correspondence with his dealer over the arrangements for the show. This was the first indication that redefining the medals, which had so occupied the artist in the winter and spring of 1942, had waned in significance by the final months of the year. 
Several factors may have come into play in this apparent shift in Smith's position regarding the medals. Among them would be the fact that Hatch had no recorded reaction to the new written material Smith had prepared for the medals. That the director of the Institute neither embraced nor rejected the text would have lessened the importance attached to those words. Also relevant was the exhibition's evolving format: no longer thought of as an exclusive showing of the medals, it had been recast as a more extensive one-person show. ${ }^{57}$ As a result, the medals were to be presented in the broader context of a range of Smith's sculpture with the effect of shifting attention away from the series.

In addition, by late 1942 Smith's actions had carried him beyond the narrow confines of the world of art into the realm of the worker. His participation in war industry legitimized his role as an anti-Fascist in a manner that no earlier political or artistic record could. No longer merely involved with abstract beliefs, or relying on actions taken among a limited, sympathetic circle of friends and fellow travelers to express his political beliefs, he was living the life of an anti-Fascist that would seem to satisfy any possible definition of the term. Smith himself had been re-presented, and therefore the series no longer needed to be enveloped in written language calculated to reorient it.

This sense was only reinforced by Smith's decisions while making the final arrangements for the Albany exhibition. He revised his earlier request to Willard that seven medals be sent to the Institute, asking instead that she send five medals - among them Munition Makers. ${ }^{58}$ This was, of course, the medal Smith had previously cited both to Willard and Hatch as the most salient example of the problems presented by the original series once the USA had entered the war. Whether this medal actually appeared in the exhibition is difficult to ascertain. But, in any event, the inclusion of this medal in his request to Willard indicates that the intense need to defend, protect, and therefore, modify the medals, that Smith had felt in May 1942, when he had first discussed the Albany exhibition, had mitigated to some extent; his perspective altered by his employment at Alco which, after all, had transformed him into a munitions maker.

While he was living an overt anti-Fascist position — making tanks for the army — returning Munition Makers to the series publicly acknowledged that he understood that there were significant flaws in the system in which he was participating. As he had written to Hatch in May, the evils identified in the medal were "still true," and while Smith was openly devoting himself to the war effort through his employment he must have felt it would no longer "confuse people" to be presented with Munition Makers. Possibly Smith became concerned that, given the reality of his work at Alco, the pendulum had swung too far, and risked moving him and his work beyond an anti-Fascist position to one that was untenable given his leftist world view. A press release on Smith issued in April 1943 offered some indication of his interest in distancing himself from Alco's 
primary contractor: "Mr. Smith says that his abstract sculptures in metal express the shape of things as he sees them; his tank welds at the American Locomotive Company, he adds, 'as the Army sees them."'59

In the end, Smith's exhibition at the Albany Institute of History and Art was held 3-28 February 1943, but there is no surviving documentation indicating which specific medals were part of the show. ${ }^{60}$ Whichever examples were on view, they had been assigned yet another name: "Medallions for the Axis."61 This newest label maintained the focus on the fascist enemy communicated by the "Axis Devastation" title in use in April and May 1942, but was more successful in preserving the ironic suggestion of the original.

Smith's sense of himself as a living, breathing example of anti-Fascism could only have been reinforced by the press coverage of the Albany exhibition. His work as an Alco welder was a useful journalistic "hook" for the area's press corps responding to the exhibition, an approach obvious even in the headlines. 62 With this context established for the medals, reporters felt no need to question the artist's intent as had been done in Minneapolis. They accepted that the series was a "protest against Fascist aggression."63 While acknowledging that the series had been "conceived and executed during the years 1935-1939,"64 press reports underscored that this was a time when Hitler and Mussolini were already involved in the "debauch of the dreadfuls." 65 Thus, they established a defence for the "early" anti-Fascism of the medals which avoided any troublesome implications of premature commitments Smith had previously acknowledged to the War Production Board. At last, the artist's public efforts as an employee of the arms industry had provided the medals with an anti-Fascism which was above reproach. In these circumstances, a new name for the series was sufficient to bring the medals into line with this thinking; individual objects and other accompanying words ceased to be an issue.

Thus, the flurry of activity regarding the meaning and presentation of the medals in 1942 accomplished one significant thing: the antiwar position which had dominated the medals' conception, execution, and early exhibition history — had been set aside in favor of a strong anti-Fascist stance. The details of the artist's strategies for re-presenting the medals ultimately were important only insofar as they supported and sustained that vital transition from opposing war to fighting against Fascism. By Spring 1943, that alteration in the fundamental meaning of the series was so firmly entrenched that the medals continued to be discussed in that vein, even when the new identifiers were no longer in use, so that when a one-person exhibition of Smith's work opened at the Willard Gallery in April of that year, critics referred to the series only by its original name - Medals for Dishonor — but consistently associated it with anti-Fascism. ${ }^{66}$ Smith's public life as an anti-Fascist arms producer came to an end in 
June or July 1944, shortly after an induction physical found him unfit for active service. ${ }^{67}$ No longer subject to the draft, he left his employment at Alco and returned to Bolton Landing, determined to make up for what he considered time lost from his work as a sculptor. ${ }^{68} \mathrm{He}$ embarked on a significantly productive period, making it possible for Willard to mount a large retrospective of his work in January 1946 which included a remarkable thirty-one sculptures produced since $1944 .{ }^{69}$

The catalogue for this exhibition was the most elaborate Willard had produced for Smith since the medals were first shown in 1940. It comprised a list of the fifty-four sculptures on view, photographs of several of the works, and an essay by prominent art historian and museum director W. R. Valentiner. The Medals for Dishonor were part of the exhibition, and Valentiner acknowledged the series' significance for Smith's early success, describing the medals as "antiwar compositions of great individuality and force." ${ }^{70}$ Robert Coates used similar terminology in reviewing the exhibition for the New Yorker when he referred to the medals as Smith's "bitingly anti-war bas-relief series of 1940. "71 With this retrospective, the presentation of the medals had come full circle; the series returned not only to its original title, but to its original meaning as the antiwar stance of the medals once again took precedence over anti-Fascism.

With the Axis powers soundly defeated, the world changed once more, altering the circumstances which made anti-Fascism the standard against which the medals were measured. If some critics were willing to acknowledge the medals as antiwar, and present them as an integral part of the development of Smith's career, others were beginning to marginalize the series altogether. The medals' traditional technique, their relatively realistic imagery and complex symbolism seemed increasingly irrelevant to those who sought to celebrate the formal achievements of Smith's more abstract pieces rendered in techniques borrowed from industrial metalworking. Not surprisingly, it was Clement Greenberg who, while presciently championing Smith as having a chance of "becoming one of the greatest of all American artists," focused on his "new unity of style," and his "classical' spareness and speed which is so indispensable to the new linear, pictorial sculpture of our time." 72

For a brief period in the early 1940s, circumstances conspired with Smith's own actions to transform the Medals for Dishonor from an antiwar statement into an anti-Fascist contribution to the United States war effort. This metamorphosis was short-lived, and not easily accomplished, but ultimately achieved Smith's goal of re-presenting the series in a manner he found appropriate for contemporary events. While he struggled with the issues involved, perhaps eventually pulling back from the implications of the mainstream antiFascism to which he had aligned himself and the medals, he never saw himself 
as having abandoned the political ideology which he had evolved in the 1930s. He had remained committed to a leftist worldview while recognizing the necessity of realpolitik when it came to prioritizing an enemies list.

Smith never again felt driven to address the global situation in so direct a manner as he had in the Medals for Dishonor. Keenly aware of the difficulty of balancing politics and aesthetics, and less pressured by the crush of current events, he returned to a "classic" visual language to respond to what he saw as the problematic conclusion of World War II in works such as Perfidious Albion,

1945 or The Royal Bird, 1948. ${ }^{73}$ Although employing a more generalised symbolism, these works explicitly extended the anti-imperialist themes of the medals; the first presenting England as a rapacious beast eager to consume the resources of the world and capable of coercing others to do its bidding, and the second offering a sovereign's vicious aerial weapon that fused primeval power with modern machinery. The emerging body of Formalist criticism served to distance critical attention from the subject matter of Smith's sculpture, further muting the message of his works in the late 1940s and 1950s. Yet just as his work as a munitions maker cemented the relationship between the medals and antiFascism, Smith's ongoing alliance with the worker through his materials and techniques served to reinforce a leftist position until the end of his life.

\section{LIST OF ILLUSTRATIONS}

1 Medals for Dishonor catalogue, Willard Gallery,1940, cover. C Estate of David Smith/Licensed by VAGA, NY. Photo credit: Courtesy The Estate of David Smith, New York.

2 David Smith, Bombing Civilian Populations, 1939, cast bronze, 10 in. $(25.4 \mathrm{~cm})$ in diameter, $7 / 8$ in. $(2.2 \mathrm{~cm})$ deep. (C) Estate of David Smith/Licensed by VAGA, NY. Photo credit: David Heald.

3 David Smith, Munition Makers, 1939, cast bronze, $9 \times 10$ fi x 7/8 in. (22.9 x $26.7 \times 2.2 \mathrm{~cm})$.

(C) Estate of David Smith/Licensed by VAGA, NY. Photo credit: David Heald. 4 David Smith, War Exempt Sons of the Rich, 1939-40, cast bronze, $101 / 4 \times 9 \times$ $7 / 8$ in. $(26 \times 22.9 \times 2.2 \mathrm{~cm})$. (C) Estate of David Smith/Licensed by VAGA, NY. Photo credit: David Heald.

5 David Smith, Sinking Hospital and Refugee Ships, 1939, cast bronze, $83 / 4$ x 12 x $7 / 8$ in $(22.2 \times 30.5 \times 2.2 \mathrm{~cm})$. (C) Estate of David Smith/Licensed by VAGA, NY. Photo credit: David Heald.

6 David Smith, Fourth Estate, 1939-40, cast bronze, 9 x $103 / 4$ x 7/8 in. (22.9 x $27.3 \times 2.2 \mathrm{~cm})$. (C) Estate of David Smith/Licensed by VAGA, NY. Photo credit: D. James Dee. 
7 David Smith, Private Law and Order Leagues, 1939, cast bronze, 10 3/4 in. (27.3 $\mathrm{cm})$ in diameter, $7 / 8$ in. $(2.2 \mathrm{~cm})$ deep. (C) Estate of David Smith/Licensed by VAGA, NY. Photo credit: David Heald. 8 David Smith, Cooperation of the Clergy, 1939, cast bronze, 10 in. $(25.4 \mathrm{~cm})$ in. diameter, $7 / 8(2.2 \mathrm{~cm})$ deep. (C) Estate of David Smith/Licensed by VAGA, NY. Photo credit: David Heald.

9 David Smith, Reaction in Medicine, 1940, cast bronze, 9 x 10 1/4 x 7/8 in. (22.9 x $26.7 \times 2.2 \mathrm{~cm}$ ). (C) Estate of David Smith/Licensed by VAGA, NY. Photo credit: David Heald.

10 David Smith, Food Trust, 1938, cast bronze, 7 fi x 14 1/4 x 7/8 in. (19.1 x 36.2 $\mathrm{x} 2.2 \mathrm{~cm}$ ).

(C) Estate of David Smith/Licensed by VAGA, NY. Photo credit: David Heald. 11 David Smith, Diplomats, 1939, cast bronze, 10 in. $(25.4 \mathrm{~cm})$ in diameter, 7/8 in. $(2.2 \mathrm{~cm})$ deep. (C) Estate of David Smith/Licensed by VAGA, NY. Photo credit: D. James Dee.

12 David Smith, Death by Bacteria, 1939, cast bronze, 10 in. $(25.4 \mathrm{~cm})$ in diameter, $7 / 8$ in. $(2.2 \mathrm{~cm})$ deep. (C) Estate of David Smith/Licensed by VAGA, NY. Photo credit: D. James Dee.

13 David Smith, Death by Gas. 1939-40, cast bronze, 10 fi x 11 fi x 7/8 in. (26.7 x $29.2 \times 2.2 \mathrm{~cm}$ ). (C) Estate of David Smith/Licensed by VAGA, NY. Photo credit: D. James Dee.

\section{NOTES}

I wish to express my appreciation to Loyola University Chicago for its support as I researched this project and prepared it for publication. Comments from an anonymous reviewer for Left History were most helpful in refining my ideas. The resources of The Estate of David Smith were vital to my work, and I am grateful to Candida Smith, Rebecca Smith, Peter Stevens, Executive Director, and Susan Cooke, Associate Director, for generously allowing me access to those materials.

1 AAA ND 1269 and ND 1 270. AAA citations refer to the David Smith Papers, or other collections as indicated, on deposit at the Archives of American Art, Smithsonian Institution. Spelling, capitalisation and punctuation from source documents have been maintained throughout the article.

2 On Smith's involvement with the communist party and his role as a fellow-traveler see, Paula Wisotzki, "Artist and Worker: The Labour of David Smith," Oxford Art Journal 28 (2005): pp. 347370 and Paula Wisotzki, "Americans Abroad: The 1930s, Politics, and the Experience of Europe," Southeastern College Art Conference Review 15 (2010): pp. 584-597. For the most comprehensive discussion of the broader implications of this topic, see Andrew Hemingway, Artists on the Left: American Artists and the Communist Movement, 1926-1956 (New Haven: Yale University Press, 2002). The standard study of the CPUSA in wartime is Maurice Isserman, Which Side Were You On? The American Communist Party During the Second World War (Middletown, Connecticut: Wesleyan University Press, 1982).

${ }^{3}$ Gerald M. Monroe, "The American Artists' Congress and the Invasion of Finland," Archives of American Art Journal 15 (1975): pp. 14-20; Matthew Baigell and Julia Williams, eds., Artists Against War 
and Fascism (New Brunswick, New Jersey: Rutgers University Press,1986); and Garnett McCoy, "The Rise and Fall of the American Artists' Congress," Prospects 13 (1988): pp. 325-340.

${ }^{4}$ Smith's gradual disengagement from political activism follows a trend long identified in studies of the USA's leftist communities generally, and one specifically addressed in two major art historical publications of the 1980s: Serge Guilbaut, How New York Stole the Idea of Modern Art: Abstract Expressionism, Freedom, and the Cold War, trans. Arthur Goldhammer (Chicago: University of Chicago Press, 1983) and Cecile Whiting, Antifascism in American Art (New Haven: Yale University Press, 1989). However, Smith's extended and multi-layered involvement with leftism well into the years of World War II has not been fully examined.

5 AAA 986-239 and 986-940.

6 The exhibition was held in November 1940. The plaques, cast in either bronze or silver, range in height and width from 10 3/4 to 14 1/4 inches. The Estate of David Smith, New York, owns the only complete set of the Medals for Dishonor. On the series, see Paula Wisotzki, "David Smith's Medals for Dishonor" (PhD diss., Northwestern University, 1988), Jeremy Lewison, David Smith: Medals for Dishonor, 1937-1940 (Leeds: Henry Moore Centre for the Study of Sculpture, 1991), and David Smith: Medals for Dishonor (New York: Independent Curators Incorporated, 1996).

7 See Wisotzki, "Critical Reception of the Medals for Dishonor," in "David Smith's Medals for Dishonor."

8 Willard reported on these developments in a letter to Smith dated 30 January 1941 (AAA ND 1 222).

${ }^{9}$ As documented in Philip A. Wright, "February exhibit includes art of Evergood, Kokoschka, Smith," Kalamazoo Gazette, 2 February 1941.

10 Reported by Willard to Smith in a letter dated 22 April 1941 (AAA ND 1 236, also 986-216).

11 Letter from Smith to Cameron Booth, St. Paul Gallery and School of Art, 28 July 1940 (AAA ND 1 1770).

12 For an overview of CPUSA positions during the Third Period and the Democratic Front, see Harvey Klehr, The Heyday of American Communism: The Depression Decade (New York: Basic Books, 1984).

${ }^{13}$ For an analysis of War Exempt Sons of the Rich, and further information about Smith's involvement with Marxist thought, see Paula Wisotzki, "Strategic Shifts: David Smith's China Medal Commission," Oxford Art Journal 17 (1994): pp. 63-77.

14 "David Smith Medals for Dishonor," In Defense of Culture: Fourth American Writers Congress and Congress of American Artists, official program of the Fourth American Writers Congress and the Congress of American Artists, 6-8 June 1941, New York City, 33. Surviving evidence suggests that the decision to submit the works was made by Willard at the last minute. (See her correspondence with Joseph Konzal, organizer of the exhibition, AAA 986-218 - 986-219.) In a letter dated 12 June 1941, Willard reported to Smith: "Seven of your medals were on display at the Anti-War show which the Congress of America Artists gave at the Hotel Commodore last week, for three days" (AAA ND 1 240, note that Willard refers to "the Anti-War show," although the program for the congress and exhibition identified it only as "the Exhibition"). Although Willard seems to have acted alone with regards to the AAC exhibition, she was familiar with the artist's long-standing relationship with the organisation and the totality of her correspondence with Smith suggests that artist and dealer shared a similar (i.e. leftist) political outlook, or at the very least that she was sympathetic to his position.

15 The seven exhibited included several of the most openly antiwar and politically radical subjects, although it omitted two of Smith's professed favourite medals - Munition Makers and Reaction in Medicine (Smith in a 1940 letter to Edgar Levy and Lucille Corcos Levy, AAA Levy Papers 145).

Originally it had been the intent of artist and dealer to illustrate the entire set of medals in the catalogue, but at the last moment the need to limit expenditures led to a decision to reproduce only 
seven of them (See AAA ND 1 189, 986-774 and 986-776). For a complete discussion of the evolution of the catalogue, see Wisotzki, "Preparations for Willard Exhibition of the Medals" in "David Smith's Medals for Dishonor."

16 Stanley Meltzoff, "David Smith and Social Surrealism," Magazine of Art 39 (March 1946): pp. 98 101. The wider currency of the term "social surrealism" has been discussed by Ilene Susan Fort, "American Social Surrealism," Archives of American Art 22 (1982): pp. 8-20, Hemingway, Artists on the Left, 4-44, and Gerrit L. Lansing, "Surrealism as a Weapon," in Isabelle Dervaux, Surrealism US A (New York: National Academy Museum, 2005).

17 AAA ND 1 212, n.d.

18 AAA 986-207, 8 January 1941. By 22 March 1941 the Museum of Modern Art had listed the Medals as one of their travelling exhibitions, although no exhibitions were generated by this action (AAA ND 1 232, also 986-214, ND 1236 and AAA 986-216). Courter was Director of the Department of Circulating Exhibitions at the Museum of Modern Art from 1935 to 1947.

19 AAA 986-211, dated 6 February 1941. For more on Katharine Kuh's storied career at the Art Institute of Chicago see her My Love Affair with Modern Art: Behind the Scenes with a Legendary Curator, edited and completed by Avis Berman (New York: Arcade Publishing, 2006).

20 Willard reminded Smith why only thirteen medals were sent to the Walker Art Center in Minneapolis which opened in November 1941: "As to the two other medals that I did not send, they were completely off the background ...." (AAA ND 1253 ).

21 AAA 986-238.

22 Willard's response: "I will keep the medals adorning the office for the Duration. Then we can break out again after all is over" (AAA ND 1 259, dated 22 December 1941).

23 AAA ND 1 265, dated 15 January 1942.

24 AAA ND 1297 and 298, undated draft.

25 There had been a second, equally negative review of the exhibition (John K. Sherman, "The Art Scene: Photo Exhibit at the Institute: Center Has Two New Shows." Minneapolis Sunday Tribune and Star Journal, [7 December 1941]), and it, too, was preserved in the Willard Gallery scrapbook (AAA ND 6 196). However, none of the surviving letters of Smith, Willard or Davidson makes direct reference to its contents.

26 Earl Browder, general secretary of the CPUSA, employed a variation on the slogan ("Communism is the Americanism of the twentieth century") in his "What is Communism?" New Masses 15 (25 June 1935): p. 14. As divisions blurred between the CPUSA and American democracy during the Popular Front, Browder ran for President in 1936 and 1940, and Smith and Dehner enthusiastically gauged the candidate's popularity in the Bolton Landing community (AAA Levy Papers 112-113). For more about Browder's perspectives on communism and American traditions see Klehr, Heyday of American Communism.

27 On Coughlin, see Alan Brinkley, Voices of Protest: Huey Long, Father Coughlin, and the Great Depression (New York: Alfred A. Knopf, 1982) and Albert Fried, FDR and His Enemies (New York: St. Martin's Press, 1999). Francis K. Pohl discusses several additional images critical of Coughlin in In the Eye of the Storm: An Art of Conscience, 1930-1970: Selections from the Collection of Philip J. and Suzanne Schiller (San Francisco: Pomegranate Artbooks, 1995), 60. Smith further accentuated the ties between the evil he "celebrated" in the medals and specific figures in the United States at the time of the Willard exhibition; for example, indicating that "Morgan interests" controlled the press (Fourth Estate), and "good crops are bad news to the trusts and the wall street manipulators" (Food Trust) (AAA Box 16 and ND 4 557).

28 The government reports to which Smith refers are the findings of the 1934 hearings of the Senate Munitions Investigating Committee (commonly known as the Nye Committee) on the circumstances surrounding the USA's entrance into World War I. The other reference is to progressive American historian Charles A. Beard whose The Rise of American Civilization, authored with his spouse 
Mary Ritter Beard and published in 1927, was a genuine best seller and offered an economic interpretation of history.

29 AAA 986-239 and 986-940, undated. Internal evidence indicates that this letter was written after Smith received Davidson's letter of 15 January 1942.

30 Smith was familiar with the annual because he had been represented by an abstract work, Growing Forms, 1939 (University of Michigan Museum of Art, Bequest of Charles E. Palmer in honor of Jean Paul Susser) the previous year.

31 As Smith developed new nomenclature for the medals he first experimented with inserting the word "Fascist" at the beginning of each title (AAA 986-255). Then, in a 21 April 1942 letter to Willard, Smith indicated that he had renamed the three by adding "Agressor [sic] Acts" to the original labels (AAA 986-256). Either of these additions would have emphatically linked the objects to the anti-Fascist position Smith had identified for the medals at the beginning of 1942. Yet when the exhibition opened, just one week later, Smith's medals appeared on the checklist with "Axis Devastation" at the beginning of each title (AAA Box 27, Misc. Publications File). The origin of this published phrase is not clear, but where "Fascist" or "Aggressor Acts" left some ambiguity about who precisely was responsible for the acts depicted in the medals or where they took place, "Axis Devastation" identified an unquestioningly evil opponent in the war effort. In 1940, Smith had presented humankind as collectively responsible for the atrocities depicted in these medals. For example, in the original caption for Sinking Hospital and Refugee Ships he indication that "mankind is food for his own brain-child."

32 AAA 986-256.

33 As was indicated previously, Smith identified Munition Makers as one of his "favorite" medals.

34 See Isserman, Which Side Were You On?

35 The checklist of the 7th Annual Exhibit of Artists of the Upper Hudson includes: 90. Axis Devastation: Death by Bacteria and 91. Axis Devastation: Death on the High Seas.

36 Letter from Dorothy Dehner, Smith's spouse, to the Levys: "We went down to Albany (as we had to go to Saratoga anyhow) for the opening of the regional show. It wasn't too much fun but it was a change to get off the mountain. They censored one of David's plaques. "Gas"' (AAA Levy Papers 421).

37 AAA ND 1269 and ND 1270.

38 Both a draft of this letter (AAA ND 1271 and ND 1 272) and the letter Smith sent to Hatch have survived (Albany Institute of History and Art).

39 Smith also altered the titles of several remaining medals. Not content to rely on "Axis Devastation" to communicate the series' anti-Fascism, Propaganda for War became "Propaganda by Aggressors," Fourth Estate was embellished with the phrase "which follows the fascist line," and Elements Which Cause Prostitution was now "Fascist Elements Which Cause Prostitution. The new titles assigned to these medals radically underscored the disconnect between the words the public would encounter and the objects themselves, given that the original titles had been incorporated into the cast designs of the medals. Perhaps because those words had been rendered in Greek, Smith felt able to overlook this conflict. (For a more on this topic see Wisotzki, "David Smith's Medals for Dishonor," 100-102.)

40 Although Smith referred to Axis cultural practice as "old," his historical references go back no further than the 1930s (Japan took control of Manchuria in 1931, the Italians invaded Ethiopia in 1935, and the infamous German bombing of Guernica took place in 1937).

41 The timeliness of the medals had been stressed in the press packet prepared by the Willard Gallery at the time of their first exhibition, where they were termed representative of "destructive forces in the world today" (See Wisotzki, "David Smith's Medals for Dishonor," 187-88). This construct seemed all the more appropriate once the United States had entered the war. Even in his December 1941 letter to Willard announcing that the medals should not be exhibited for the "dura- 
tion," Smith observed that "[t]heir classic value is apt to be misunderstood as unpatriotic at the present time” (AAA 986-238).

42 Shortly after sending the letter to Hatch detailing the reconstituted series, Smith affirmed those changes in a letter to Willard informing her of the upcoming exhibition at the Albany Institute (AAA 986-745 -986-748, dated 15 May [1942]).

43 Levy Papers 179, n.d. Internal evidence indicates this letter was written during summer 1942.

44 Dehner to Levys, n.d., AAA Levy Papers 182. Dehner to the Levys, n.d., AAA Levy Papers 175. Also Dehner to Willard, n.d., AAA 986-756.

45 AAA 986-236, letter from Smith to Willard, dated 22 September 1940. Roosevelt approved the Selective Training and Service Act on 16 September 1940. Although Smith would turn thirty-six in 1942, Congress had, after Pearl Harbor, extended the draft to men aged thirty-eight (and briefly to forty-five). According to Dehner, Smith felt an environment which sanctioned violence was inappropriate, even dangerous, for his quick-tempered personality, already inclined toward expressions of physical force (author's interview with Dorothy Dehner, June, 1985).

46 AAA 986-246, letter from Smith to Willard, dated 2[?] March 1942. Artists for Victory was a loose affiliation of professional organisations which sought to "to render effective the talents and abilities of artists in the prosecution of World War II and the protection of this country." Ellen Landau, Artists for Victory (Washington, D.C.: Library of Congress, 1983), 2.

4730 May 1942. Typewritten draft of the letter preserved in Smith's papers as AAA ND 1280 and ND 1 281. Portion of handwritten draft, AAA ND 1 296. Smith eventually found a project in line with these goals in a commission for a medal to honor Americans serving the Chinese government. (See Wisotzki, "Strategic Shifts").

48 AAA ND 1281.

49 Nathan offered a polite, if brief, response to Smith informing him that his letter had been forwarded to the person in charge of labour morale (AAA ND 1 286, dated 6 June 1942).

50 AAA 986-255, letter from Smith to Willard, dated 21 April 1942.

51 AAA 986-260, dated 19 July 1942.

52 For more on this topic, see Wisotzki, "Artist and Worker."

53 AAA 986-274, letter from Smith to Willard, dated 14 October 1942.

54 Willard to Smith, 23 October 1942, AAA ND 1 292. Smith to Willard, n.d., AAA 986-786.

55 AAA ND 1294.

56 The checklist for the Artists for Victory Exhibition is preserved as AAA ND 5 316-317, and in the Levy Papers, Box 10.

57 This exhibition was to be held simultaneously with one by Dehner.

58 AAA 986-751, n.d. Contents indicate the letter was written shortly after Christmas Day 1942. The four other medals Smith indicated were to be included in the exhibition had been part of the series as he had reconstituted it for Hatch in April 1942.

59 Typescript of press release dated 6 April 1943, issued by Earl Newsom and Co., New York City, to accompany photographs that had been taken of Smith at work at Alco (David Smith Papers, Box 20, File Reviews).

60 The exhibition took place concurrently with the exhibition of Dehner's work (as noted above) and the Institute's Third America Drawing Annual. The only clues to the actual composition of Smith's exhibition were provided by press coverage, see below.

61 "Medallions for the Axis" was consistently employed in references to the February 1943 exhibition.

62 “Sculptor, Alco Employe will Exhibit Work: David Smith Uses Metal Knowledge as Welder; 
Wife's Paintings Also To Be Shown in Albany," unsigned article in Schenectady Garette, 1 February 1943 (AAA ND 6 222), and Clif Bradt, "Few Welders at ALCO Plant Know Their 'Buddy' is Famed Sculptor," Knickerbocker News 3 February 1943 (AAA ND 5 754).

63 AAA ND 6222

64 AAA ND 6222.

65 AAA ND 5754.

66 While no medals were actually on view, the exhibition included five recent drawings whose titles and imagery encouraged connections to the earlier series (Checklist of the exhibition, AAA N96-114, frame 215). Although their imagery shared some of the visual themes of the medals, the new drawings made more specific references to current events in these drawings, for example, he included Hitler's image in Aryan Fold (Type I), 1943 (The Estate of David Smith, New York). To some extent these drawings were the timely, overt anti-Fascist images the medals had become only as a result of Smith's careful and selective re-presentation.

The reviews of Howard Devree and Maude Riley are among those that specifically refer to the Medals for Dishonor. (Howard Devree, "From a Reviewer's Notebook," The New York Times, 11 April 1943, preserved among Smith's papers, AAA ND 5 755, and Willard's papers, N69-114, frame 216. M[aude] R[iley], "David Smith, Courtesy American Locomotive," Art Digest 17 (15 April 1943): p. 13, preserved among Willard's papers, AAA N69-114, frame 216). The anonymous reviewer for Newsweek used the term "anti-Fascist," while Devree and Riley used terms that had similar associations (i.e., "evil forces in the world today" and "Nazi atrocities.") ("Welder-Sculptor," Newsweek, 19 April 1943, pp. 76-78, preserved among Willard's papers as AAA N69-14, frame 217.)

${ }^{67}$ Smith was instructed to report for a pre-induction physical examination on 15 February 1944 (AAA ND 1333 ). Willard's enthusiastic reaction to news that he had avoided the draft appeared in a letter of 19 February 1944 (AAA ND 1335 ). Smith stopped working for Alco in late June or early July, 1944 (D298 1675, letter from Smith to Dehner, 10 June [1944], and D298 1662, letter from Smith to Dehner, 4 July [1944]).

68 AAA 986-279.

${ }^{69}$ Checklist of the exhibition, preserved as AAA N69-114, frame 295.

70 While the medals were listed as a single item, more than one, but probably not all fifteen, were included in the exhibition. Robert M. Coates, "The Art Galleries: Past and Present," New Yorker, 12 Janury1946, pp. 49-50, “... 'Medals for Dishonor,' of which a few are in the show” (AAA ND 6208 209 and N69-114, frame 302). For a fuller discussion of the genesis and content of Valentiner's essay for the 1946 catalogue, see Wisotzki, "David Smith's Medals for Dishonor," 305-309. More on his career can be found in Margaret Sterne, The Passionate Eye: The Life of William R. Valentiner (Detroit: Wayne State University Press, 1980).

71 Coates, AAA ND 6208 and ND 6209.

72 "Becoming ...", Clement Greenberg, "American Sculpture of Our Time: Group Show,” Nation 156 (23 January 1943): pp. 140-1. "New ...” and “"classical' ...", Clement Greenberg, "Art," Nation (19 April 1947): pp. 459-60, AAA N69-114, frame 338.

73 Perfidious Albion exists in three versions: one is owned by the Estate of David Smith, New York, a second is in the Raymond and Patsy Nasher Collection, Dallas, Texas, and the third is in the collection of Jon \& Mary Shirley. The Royal Bird is owned by the Walker Art Center, Minneapolis, Gift of the T. B. Walker Foundation, 1952. Robert Lubar's "Metaphor and Meaning in David Smith's Jurassic Bird," Arts 59 (1984): pp. 78-86, remains a crucial text on these and related objects. See also, Wisotzki, "David Smith's Medals for Dishonor," 274-303. 